症例

輸血後の Kidd抗体による溶血性貧血の 1 例

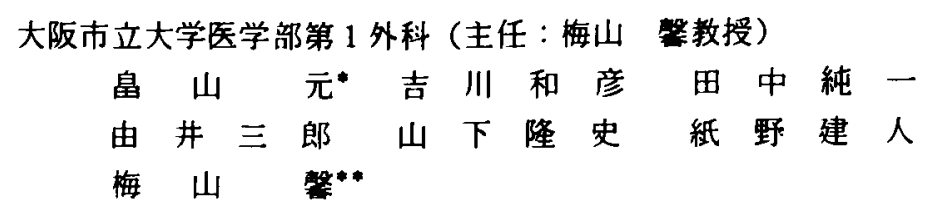

同 輸血部 村井順一郎 黒木哲夫

\title{
HEMOLYTIC ANEMIA ASSOCIATED WITH ANTI-KIDD ANTIBODY AFTER BLOOD TRANSFUSION-A CASE REPORT-
}

Gen HATAKEYAMA, Kazuhiko YOSHIKAWA, Junichi TANAKA, Saburo YUI, Takafumi YAMASHITA, Kenjin KAMINO and Kaoru UMEYAMA

1 st. Department of Surgery, Osaka City University School of Medicine (Director : Prof. Kaoru Umeyama)

Junichiro MURAI and Tetsuo KUROKI

Division of Blood Transfusion, Osaka City University School of Medicine

(1) 輸血後に不規則抗体が出現し，溶血性實血を呈することは比較的稀とされている.

(2) われわれは特発性門脈圧穴進症 (IPH)の食道静脈瘤に対し経腹的食道離断術兼摘 脾術を行ない, その際 $2.000 \mathrm{ml}$ の俞血を行なった後に, 極めて珍らしいKidd 抗体（抗 $\mathrm{JK}^{\mathrm{b}}$ ）が出現し，術後溶血性賓血を併発した症例を経験した。

(3) 現在までにかかる不規則抗体は10数種類が知られているが，このらち Kidd 抗体は 本邦においては1970年から1979年までの10年間で，われわれの集計しえたかぎりでは10 例の報告が見られるにすぎず，極めてまれなむのと思われる。

(4)このよらな渝血後の不規則抗体の出現による溶血を避けるためには，渝血前にかか る抗体の存在することも考虑して，不規則抗体のスクリーニングを必ず行ならべきであ ると思われ，若干の文献的考察を加光て報告した。

\section{粕}

輸血後に不規則抗体の出現によって溶血性貧血が出 現することは比較的稀なるのとされている.われわれ は特発性門脈圧え進症 (以下 IPH と略す) の食道静脈 瘤に対し経腹的食道離断術兼摘脾術をおこない，その 際に, $2,000 \mathrm{ml}$ の大量輸血を行なった後に, 日本人では 極めてめずらしいといわれている Kidd 抗体が出現 し，溶血性賁血を併発した症例を経験したので，若干 の文献的考察を加えて報告する。

\section{症例}

患者：56歳，女性，主婦。

主訴：吐血.

家族歴：母が胃癌にて死亡。他に特記すべき事項は ない.

既往歴：46歳時, 右乳癌にて定型的乳房切断術を受 け，その際，量は不明であるが輸血を受けた。 その後， 肝炎を併発し，約 1 カ月間の加療にて軽快している.

現病歷：約20年前, 野外作業中に量は不明であるが 吐血した。しかし特に治㞠を受けず放置していた。昭 和48年再度吐血があり, 某病院入入院し, 保存的治愿 にて軽快した。昭和 55 年 9 月 1 日，大量の吐血下血か

" 臨床研究医 $\cdots$ 直接指導者 
あり、某病院へ㗨急入院し, 肝硬変の診断にて保存的 療法を受け9月18日退院した。その後, 特に愁訴なく 経過していたか，精査目的にて当院第三内科を受診し た. 検查の結果, 脾腫, 胆石症, 食道静脈瘤を指摘さ れ, 昭和56年 2 月 13 日に手術目的にて当科入入院した。

入院時所見：体格栄養中等度，意識清明，表在リン 八節は触知せず，眼瞼結膜は軽度貧血がみられ，眼球 結膜は黄染なく，胸部では右胸壁に定型的乳房切断術 による瘦痕をみとめる以外理学的所見上異常を認めな かった。腹部では脾藏は触知せず訮臓は剣状突起下約 二横指触知した。

入院時検査成績は表 1 のごとくで赤球数 397 万, 白血 球数 2,900 , 血小板数 11.7 万と沉血球减少がみられた.

肝機能検查ではICGがやや高値を示した以外に異 常所見はみとめられなかった，又，軽度の腎障害を認 めたが，心肺機能に異常は認めなかった。

血液型は $\mathrm{O}$ 型 $\mathrm{Ph}$ (D) 陽性で，クームス試験は直接,
間接共に陰性であった。また術前抗体スクリーニング にて不規則抗体は検出されなかった。

食道胃腸透視では，食道上部まで達する屈曲蛇行す る著明な静脈瘤を認めた (図 1 ). また内視鏡検查では, 食道中部まで達する $3 \sim 4$ 条の食道静脈瘤がみられ， Cherry red, Hematocystic spot, を中心とする Red color signも認められた.

以上より食道静脈瘤を伴う IPH の診断にて昭和56 年 3 月 6 日経腹的食道離断術および摘脾術と胆要摘出 術を施行した。

開腹時の門脈圧は340 $\mathrm{mmH}_{2} \mathrm{O}$ で, 摘脾後は270 $\mathrm{mmH}_{2} \mathrm{O}$ であった. 摘出脾の重量は $300 \mathrm{~g}$ で術中の輸血 量は2,000ml であった，術中生検による肝葴の組織所 見では為小葉形成に至らないが, 線維化の程度は強く, 乙'型肝硬変像を呈し, 脾葴は洞增生の所見が認められ た.

術後良好に経過していたが，術後 7 日目頃より負血

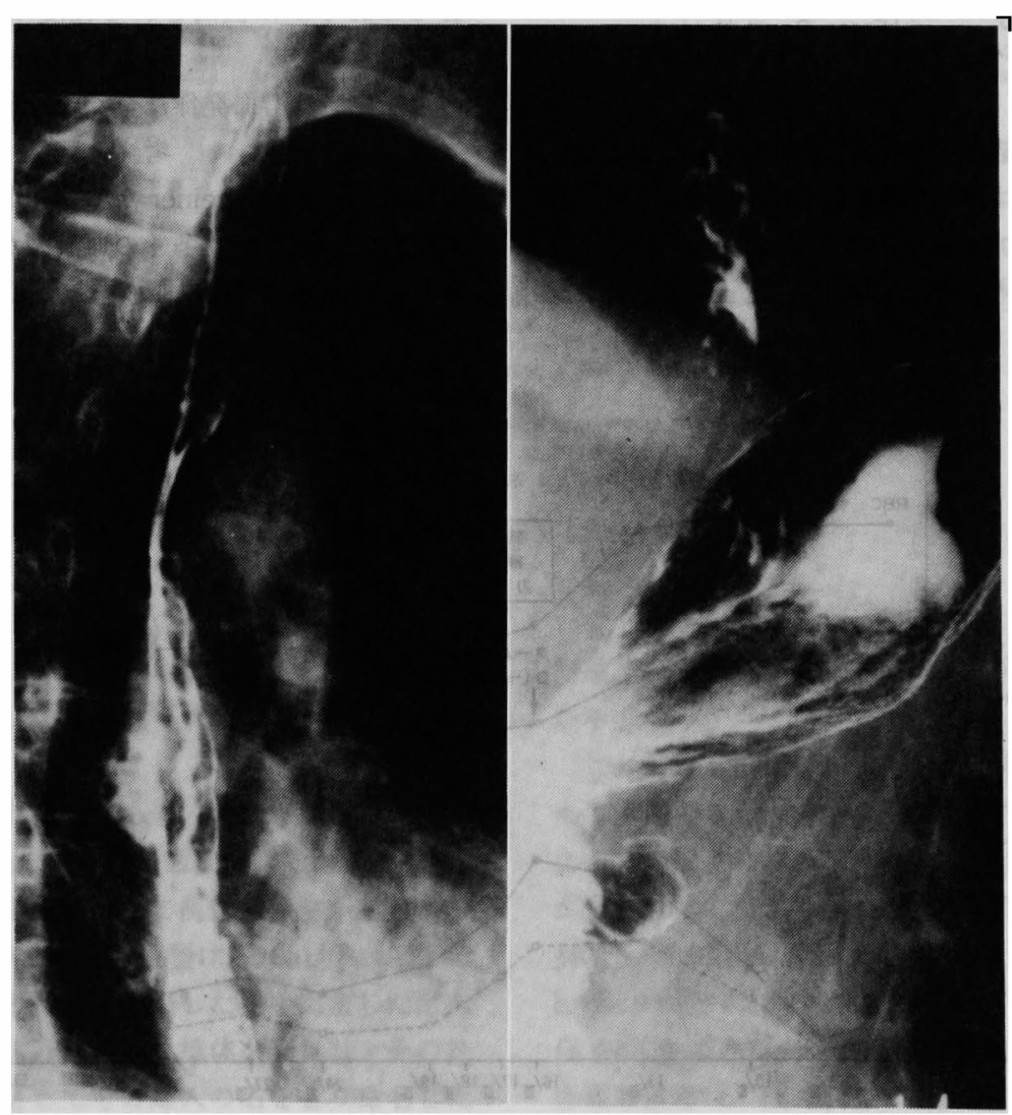

図 1 食道胃腸透視では, 上部食道まで達する屈曲蛇行する著明な食道静脈瘤を認め た。 
表 1 Laboratory findings

\begin{tabular}{|c|c|c|c|}
\hline \multicolumn{2}{|l|}{ Blood analysis } & \multirow[b]{2}{*}{ YGTP } & \multirow[b]{2}{*}{$20 \mathrm{mU} / \mathrm{ml}$} \\
\hline RBC & $397 \times 10^{4} / \mathrm{mm}^{3}$ & & \\
\hline $\mathrm{Hb}$ & $10.6 \mathrm{~g} / \mathrm{d} \ell$ & LDH & 292 WU \\
\hline Ht & $32.3 \%$ & ICG $\left(15^{\prime}\right)$ & $16 \%$ \\
\hline WBC & $2900 / \mathrm{mm}^{3}$ & Rmax & $2.5 \mathrm{mg} / \mathrm{kg} / \mathrm{min}$ \\
\hline Bas & $1.0 \%$ & T. G. & $117 \mathrm{mg} / \mathrm{dg}$ \\
\hline Eos & 1.0 & T. Chol. & $156 \mathrm{mg} / \mathrm{dl}$ \\
\hline M-bl & 0.0 & TTT & 2.30 \\
\hline Prom & 0.0 & ZTT & 8.30 \\
\hline Myel & 0.0 & BUN & $32 \mathrm{mg} / \mathrm{d} \ell$ \\
\hline Meta & 0.0 & Creatinine & $1.9 \mathrm{mg} / \mathrm{d} / \mathrm{s}$ \\
\hline St & 13.0 & FES & $89 \mathrm{mg} / \mathrm{d} \ell$ \\
\hline Seg & 41.0 & NH, & $32 \mu g / d \ell$ \\
\hline Ly & 38.0 & Electrolyte & \\
\hline Mon & 2.0 & $\mathrm{Na}$ & $138 \mathrm{mEq} / \mathrm{L}$ \\
\hline Plasma & 0.0 & $\mathbf{K}$ & $4.9 \mathrm{mEq} / \mathrm{L}$ \\
\hline Reticulocyte & $30 \%_{0}$ & Cl & $103 \mathrm{mEq} / \mathrm{L}$ \\
\hline platelet & $11.7 \times 10^{4} / \mathrm{mm}^{2}$ & Serological $t$ & \\
\hline Blood Chemiste & & CRP & - \\
\hline TP & $7.9 \mathrm{~g} / \mathrm{d} \Omega$ & RA & $2+$ \\
\hline alb & $4.4 \mathrm{~g} / \mathrm{dl}$ & Wa-R & + \\
\hline$a,-g l$ & $3.5 \%$ & Hbs-Ag & - \\
\hline$\alpha_{2}=90$ & $6.8 \%$ & Hbs-Ab & 75 \\
\hline$\beta-g e$ & $12.6 \%$ & AFP & 4.1 \\
\hline$\gamma \cdot g \ell$ & $17.8 \%$ & DNA & $<40$ \\
\hline T. Bil & $1.1 \mathrm{mg} / \mathrm{d} s$ & LE & - \\
\hline direct Bil & $0.6 \mathrm{mg} / \mathrm{dg}$ & ESR $\quad 18 \mathrm{~mm}$ & $1 \mathrm{hr}) 49 \mathrm{~mm}(2 \mathrm{hr})$ \\
\hline GOT & $33 K U$ & Urinalysis & n.p. \\
\hline GPT & $28 \mathrm{KU}$ & Feces Occu & blood $t$ \\
\hline$A \mid-P$ & $9.7 \mathrm{KAU}$ & Para & le $\quad-$ \\
\hline
\end{tabular}

が出現し，また球結膜の黄染も認められるようになっ た. 術後 10 日目には赤血球数 $283 \times 10^{4} / \mathrm{mm}^{3}, \mathrm{Hb8} .6 \mathrm{~g} /$ dl, Ht25.4\%となり，400ml の輸血にすかかわらず費 血はあまり改善せず LDH は581WU と上昇し，血中総
表 2 Anti JK'の抗体洒の推移

\begin{tabular}{r|c|c|c|c|c|c}
\hline 月日 & 3.3 & 3.17 & 4.10 & 4.18 & 4.25 & 5.7 \\
\hline $\mathrm{Jk}^{\mathrm{b}}$ & $(-)$ & 64 & 8 & 2 & 2 & 2 \\
\hline $\mathrm{Jk}^{\mathrm{a}+\mathrm{b}}$ & $(-)$ & 32 & 8 & 2 & 2 & 2 \\
\hline
\end{tabular}

* Anti Jk 以外の不規則抗体は梌出されなかった

ビリルビン值 $5.6 \mathrm{mg} / \mathrm{dl}$ と高值を示し, 間接ビリルビ ン值は3. $2 \mathrm{mg} / \mathrm{dl}$ と溶血性䏝血の像を示した（図 2 ）.

術後11日目の抗体スクリーニングにて赤血球 $\mathrm{JK}^{\mathrm{b}}$ 抗 原に対する抗 $\mathrm{JK}^{\mathrm{b}}$ 抗体が抗体価64倍と高值を示すよ5 になり JK抗原陰性の血液のみを $600 \mathrm{ml}$ 輸血した。 こ の輸血後 5 日目頃より賓血は改善し, 輸血啳 8 日目に は, $\mathrm{Hbl} 2.7 \mathrm{~g} / \mathrm{dl}$, 赤血球数 $413 \times 10^{4} / \mathrm{mm}^{3}, \mathrm{Ht} 39.4 \%$ と 正常域に復した。

一方抗 $\mathrm{JK}^{\mathrm{b}}$ の抗体価の推移は，JK㣌抗原陰性の血液 を輸血後17日目には抗体価が64倍あったるのが 8 倍 に，44日目では 2 倍と低い值を示すようになり，64日 目ではわずかに検出される程度の低抗体価となった

(表2).

現在患者は溶血発作は全くなく経過している.

考察

1901年に Landsteiner がヒトで最初の ABO 式血液 型を発見して以来，多くの血液型が発見されてきた。

これらのうち $\mathrm{ABO}$ 式血液型以外の抗原の種類や抗原

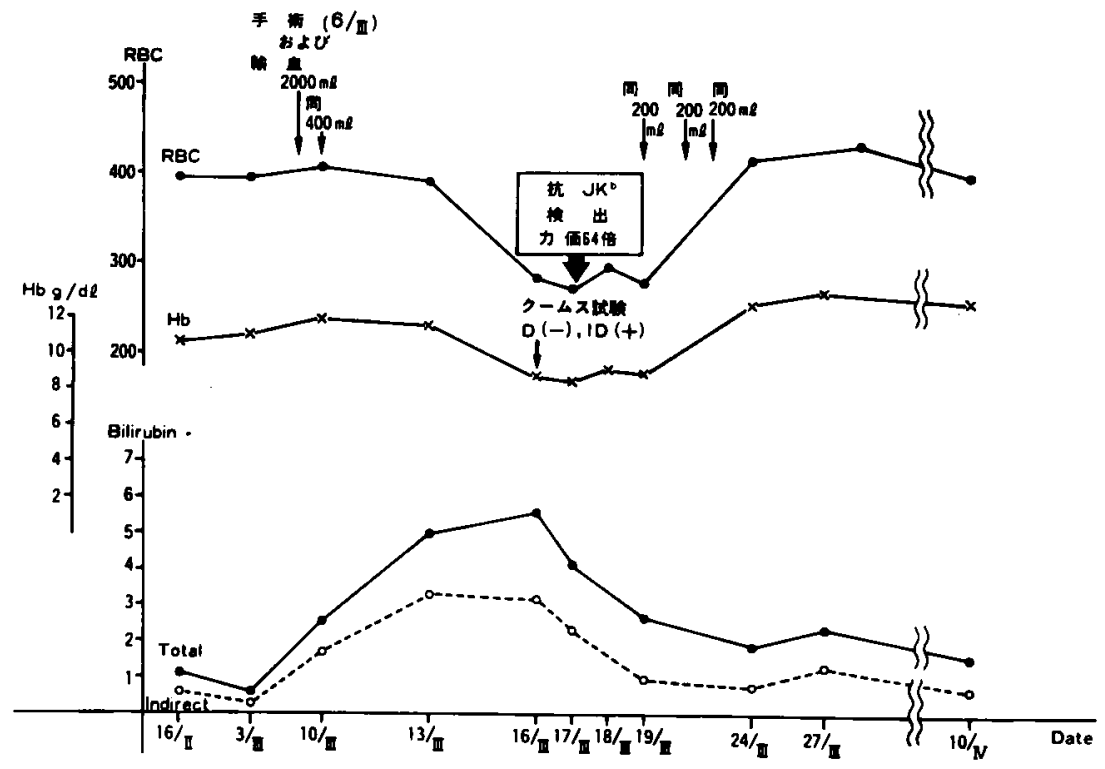

図2 臨床経過：術後 7 日目ごろより費血が増強し, 街後11日目に力価64倍の抗 $\mathrm{JK}^{\mathrm{b}}$ 抗体が検出された。 
费 3 Discovery of main blood group systems*

\begin{tabular}{|c|c|c|c|c|}
\hline \multicolumn{2}{|c|}{ Blood group system } & \multicolumn{3}{|c|}{ First examples of antibody defining system } \\
\hline \multirow[b]{2}{*}{$\begin{array}{c}\text { Name } \\
\text { (abbreviation) }\end{array}$} & \multirow[b]{2}{*}{$\begin{array}{l}\text { Year of } \\
\text { discovery }\end{array}$} & \multirow[b]{2}{*}{ Found in serum of } & \multicolumn{2}{|c|}{ Detected by } \\
\hline & & & $\begin{array}{l}\text { Agglutination } \\
\text { of red cells in } \\
\text { saline }\end{array}$ & $\begin{array}{l}\text { Antiglobulin } \\
\text { test }\end{array}$ \\
\hline $\mathrm{ABO}$ & 1901 & \multirow{2}{*}{ Normal subjects } & \multirow{2}{*}{ Yes } & \multirow{2}{*}{-} \\
\hline Lewis (Le) & 1946 & & & \\
\hline MN & 1926 & \multirow{2}{*}{$\begin{array}{l}\text { Rabbits injected with human red } \\
\text { cells }\end{array}$} & \multirow{2}{*}{ Yes } & \multirow{2}{*}{-} \\
\hline $\mathbf{P}$ & 1926 & & & \\
\hline \multirow{3}{*}{ Rhesus (Rh) } & \multirow[t]{2}{*}{1940} & $\begin{array}{l}\text { (i) Rabbits and guineapigs } \\
\text { injected with rhesus } \\
\text { monkey red cells }\end{array}$ & Yes & 一 \\
\hline & & (ii) Transfused patients & Yes & $-t$ \\
\hline & 1941 & $\begin{array}{l}\text { (iii) Mothers of infants with } \\
\text { haemolytic disease of the } \\
\text { newborn }\end{array}$ & Yes & -1 \\
\hline Lutheran (Lu) & 1945 & Transfused patient & Yes & - \\
\hline Kell (K) & 1946 & \multirow{8}{*}{$\begin{array}{l}\text { Transfused patients or } \\
\text { mothers of infants with } \\
\text { haemolytic disease of the } \\
\text { newborn }\end{array}$} & \multirow{8}{*}{ No } & \multirow{8}{*}{ Yes } \\
\hline Duffy (Fy) & 1950 & & & \\
\hline Kidd (Jk) & 1951 & & & \\
\hline Diego (Di) & 1955 & & & \\
\hline Yt & 1956 & & & \\
\hline $\mathbf{X g}$ & 1962 & & & \\
\hline Dombrock (Do) & 1965 & & & \\
\hline Colton $\left(\mathrm{C}_{0}\right)$ & 1967 & & & \\
\hline li & 1956 & $\begin{array}{l}\text { Patients with 'cold' autoimmune } \\
\text { haemolytic anaemia }\end{array}$ & Yes & - \\
\hline
\end{tabular}

The word 'main' is arbitrary: systems omitted from the table include $\mathrm{Au}, \mathrm{Sc}, \mathrm{Cs}, \mathrm{Sd}, \mathrm{Bg}$, $\mathrm{Ch}$, and $\mathrm{Wr}$.

- : not done, $\dagger:$ The antiglobulin test was introduced into

clinical work in 1945 ; it was soon realized that many $R h$ antibodies which could be detected by this test would not agglutinate red cells suspended in saline.

* Mollison, P. L. : Blood Tranfusion in Clinical Medicine, Blackwell Scientific Publication,P170，1979より引用

の発現の頻度についても詳しく調べられているが，そ のらち臨床上重視されているものは10数種類がある1

\section{(表 3 ).}

これらの抗原のうちで, Kell, Duffy, Kidd, Diego, $\mathrm{Yt}, \mathrm{Xg}$, Dombrock, Colton 式血液型は輸血もしくは, 母児血液型不適合妊娠によって抗体の産生が見られる と言われている，Kidd 式血液型は，1951年に Allen ${ }^{2)}$ か，典型的な胎児赤芽球症を呈した児を出産した婦人 の血清中に従来見られなかった抗体を発見し，その抗 体に対応する抗原としてその婦人の名をとり命名した $\mathrm{JK}^{\mathrm{a}}$ と1953年に Plaut ${ }^{3}$ にとより，JK (a+)の血液型の婦 人の血清中に存在する抗体から JK' ${ }^{\mathrm{b}}$ 抗原が発見されて
以来, Kidd 式血液型は表 4 のごとく 4 型にわけられて いる.

これらの Kidd 抗原の表現型は常染色体上に座を占 める優劣のない一対の対立遭伝子である $\mathrm{JK}^{\mathrm{a}}, \mathrm{JK}^{\mathrm{b}}$ に よって支配されており，日本人では，現在までに三型 が発見されており，その頻度は，JK $(\mathrm{a}+\mathrm{b}-) 15.9 \%$ ， $\mathrm{JK}(\mathrm{a}+\mathrm{b}+) 44.4 \%, \mathrm{JK}(\mathrm{a}-\mathrm{b}+) 39.7 \%$, JK $(\mathrm{a}-$ b一） $0 \%$ とされている(表 $4^{4)}$ )。 今回の自験例は JK

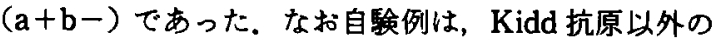
赤血球抗原は， D, E, c, e, M, P 2 の抗原か陽性で， C, $\mathrm{N}, \mathrm{P}_{1}, \mathrm{Le} \mathrm{e}^{\mathrm{a}}, \mathrm{Le} \mathrm{e}^{\mathrm{b}}$ の抗原は陰性であった（表 5 ）.

これら ABO 抗原以外の赤血球抗原に対応寸る抗体 
表 4 Kidd 式血洨型

\begin{tabular}{|c|c|c|c|c|c|}
\hline 血藕 & 聇 & 血球 & の反心 & 顷 & 度 (\%) \\
\hline 表現型 & 造伝子型 & 抗 Jk“ & 抗 Jkb & 日本人 & 白 人 \\
\hline$J K(a+b-)$ & $J k \cdot J k=$ & + & - & 15.9 & 26.4 \\
\hline$J k(a+b+)$ & $J k$ JJkb & + & + & 44.4 & 50.0 \\
\hline$\sqrt{k}(a-b+)$ & JkbJkb & - & + & 39.7 & 23.6 \\
\hline$J K(a-b-)$ & JkJk & - & - & 0 & こく称 \\
\hline
\end{tabular}

表 5 赤血球抗原

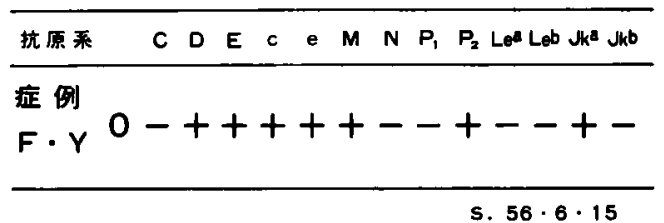

表 6 日本における Kidd 抗体の出現例（1970～1979）

\begin{tabular}{|c|c|c|c|c|}
\hline & 年 & A & 原㾣 & ( \\
\hline 1 & 1970 & 执JK・ & ITP & 策谷的 D \\
\hline 2 & 1972 & tJJ" & 不 明 & 片早， \\
\hline 3 & 1974 & 枕JK" & 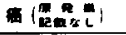 & 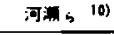 \\
\hline 4 & 1975 & 抗JK" & AML & 格木；的 \\
\hline 5 & 1977 & 机 ${ }^{\circ}$ & 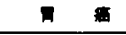 & 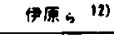 \\
\hline 6 & 1979 & 氿JK・ & 不 明 & (f) \\
\hline 7 & 1979 & 枕JK. & 不 & 只舟， 14) \\
\hline 8 & 1979 & tJKe & 不 明 & E田 ${ }_{s}|9\rangle$ \\
\hline 9 & 1979 & 林JKb & 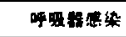 & (P) \\
\hline 10 & 1979 & 执JK' & 棉盘 & 田中， 13) \\
\hline 11 & 1981 & 枕J" & IPH & 自罢哩 \\
\hline
\end{tabular}

は一般に不規則抗体と乎ばれており，本邦での報告に 上るその頻度は，供血者の $0.1 \sim 0.3 \%$, 受血者の $1 \%$ 前後にみられる5゙いわれている.これら多くの不規 則抗体の検出例の中で Kidd 抗体が検出される頻度は 極めて少なく,0.2〜0.7\%といわれている.また JKa抗 原, $\mathrm{JK}^{\mathrm{b}}$ 抗原が陰性の受血者への 1 回の輸血での免度 成立の頻度は，Williams ${ }^{6}$ によると，それぞれ0.07\%， $0.03 \%$ とその頻度は極めて少ないとしている。

Kidd 抗体は抗体産生の機序から見ると,自然抗体で はなく免度抗体であるが, Polley ら》の15例の検討に 上ると，免疫クロブリン分画の5ち，12例が IgG，2例 が IgM，1 例が IgG と IgM の混在であったと報告し ているように, ほとんどが IgGに属し，一部 IgM を含 んでいると考えられている。反応様式は不完全抗体で あり，補体結合性を有し， $37^{\circ} \mathrm{C}$ が反応至適温度の温式 抗体で，検出には間接クームス試験が最も良いとされ
ている、しかし凝集反心が弱い場合は fucinもしくは tripsinで処理した後に間接クームス試験を行ならと 強い凝集反応が得られる゙といわれている。

本邦における Kidd 抗体の検出報告例は，1970年か ら1979年までの過去10年間にわれわれが集計しえたか ぎりでは10例の報告がみられているにすぎない(8) 17) (表 6 )。この5ち抗 $\mathrm{JK}^{\mathrm{a}}$ は 4 例, 抗 JK $\mathrm{JK}^{\mathrm{b}} 6$ 例で, 抗 $\mathrm{JK}^{\mathrm{b}}$ 症例がやや多くみられているが Plaut ${ }^{3 /}$ による と抗 $\mathrm{JK}^{\mathrm{b}}$ は抗 $\mathrm{JK}^{\mathrm{a}}$ より稀であるとし，かつ他の不規則

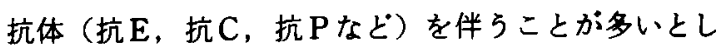
ている。本邦報告例でも，抗 $\mathrm{E}$ ，抗C，抗 Pなどの不 規則抗体を伴う例が多いが，自験例は抗 $\mathrm{JK}^{\mathrm{b}}$ みが検 出され，他の不規則抗体は検出されなかった。これら Kidd 抗体の検出例は1970年から10年間の5ち1979年 の報告が10例中 5 例之半数を占め，不規則抗体スク リーニングが最近碽極的に行なわれるよらになってき たことをらかがわせ，今啳はその検出頻度が増加する 可能性があると思われる。 の関係は, 文献上記載の明らかなるのについてみると， $400 \mathrm{ml} \sim 4,000 \mathrm{ml}$ の範囲であり，特に輸血量との相関 はないよらに思われた。 また原疾患との関係でる悪性 腫昜例が多く，免疫学的に不規則抗体が出現しやすい と思われる症例ではなかった。

Kidd 抗体に上る塎血については，1958年に，

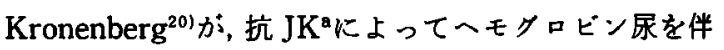
う重症の溶血を打こすことを報告し，1959年には

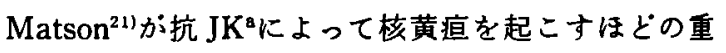
症の新生児溶血性黄疾の症例を報告している。ささらに Dorner ${ }^{22)} ら は 1974$ 年に Kidd 式血液型不適合妊娠によ る新生児溶血性黄疸 16例の報告例を検討し抗 JKaよ るむの12例，抗 JK'によるすの 4 例であったとしてい る。輸血による溶血性蔶血としては欧米では抗 $\mathrm{JK}^{\mathrm{a}}$ よるものが多く見らけられるが，本邦では伊原ら ${ }^{122}$ か， 1977年に抗 JK $+\mathrm{E}+\mathrm{E} に よ る$ 溶血の 1 例を報告してい る.

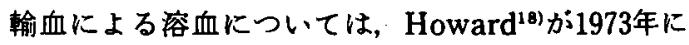
Delayed hemolytic transfusion reaction（遅延型溶血 性輸血反応）として報告している。遅延型客血性输血 反応の臨床症状は，輸血直後はなんら症状を呈さず， 数日経過してから急激な血中へモグロビン値の低下 と，血中ビリルビン值の上昇を認め, 影性黄疸が出現 するようになり，まれにはへモグビン尿を認めるこ ともある。

かかるKidd 抗体による溶血は血管内溶血といら形 
をとるといわれ，輸血当時は輸血された赤血球を破壤 するのに充分な抗体がなく，数日たってから抗体価か 上昇し，抗体で感作された血球が細網内皮系，特に肝 䁍で処理されることによると考えられている1199.

このよ5に Kidd 抗体による副作用については軽症 にとどまる症例から重篤な症状をしめす症例まであ ク，抗体が検出された症例については臨床経過の敩重 な follow upが必要であると思われる。

Kidd 抗体も含めた不規則抗体による副作用に対す る予防対策は，渝血を施行する予定の患者血清を，： ネル血球によってあらかじめ不規則抗体のスクリーニ ングを行なって，陽性のものはその抗体を同定し，対 応抗原が陰性の血液のみを㡏血するようにすることが 必要である。 またわれわれの症例のように術前の不 規則抗体のスクリーニングでは, 不規則抗体は検出さ れず，術中輸血によって抗 JK'が出現したよらに,一度 輸血を行なった症例で再榆血を必要とする際は，不規 則抗体の存在を考虑してスクリーニング検査を必ず行 ならべきであろら。

\section{桔語}

今回われわれは術中術後の輸血の後に極めて稀な Kidd 抗体 (抗 $\mathrm{JK}^{\mathrm{b}}$ ) の出現による溶血性貧血がみられ た1例を経呀したので，若干の文献的考察を加えて報 告した。

本論文要旨の一部は第335回大阪外科集談会で発表した。

\section{文嗝}

1) Mollison, P.L.: Blood Tranfusion in Clinical Medicine, Blackwell Scientific Publication, p. 170, 1979.

2) Allen, F.H. Jr, Diamond, L.K. and Niedziela, B.: A new blood-group antigen. Nature, 167 : 482, 1951.

3) Plaut, G., Ikin, E.W., Mourant, A.E., et al.: A new blood group antibody,anti-JK ${ }^{b}$, Nature, $171: 431,1953$.

4）遠山 博：渝血学, 中外医学社，東京, p. 184, 1979.

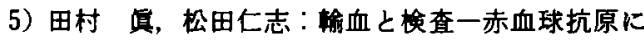
対する抗体を中心として一，内科，48：617-624， 1981.

6) Williams, W.J.: Hematology, McGraw-Hill, New York, p. 1272, 1972.
7) Polley, M.J.: The role of $19 \mathrm{~s}$ gamma globulin blood group antibody in the antiglobulin reactions.Brit. J. Haemat., 8: 149, 1962.

8）態谷 崇, 西村要子, 藤江良郎他：最近経験した抗 $\mathrm{JK}^{a}$ 抗体の1例, 日本輸血学会倠誌, $17: 89,1970$.

9）片野公子，山田恵子，永島重子他：不規則抗体を証

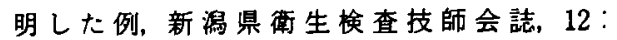
219-220, 1972.

10）河瀬正晴, 原 功, 望月憲雄：温性抗 $P_{1}$ 抗体之 抗 JK抗体の湦在例について, 日本渝血学会雅誌, $12: 17-19,1974$.

11）松本剛志，渡部和子，山口英子他：抗 $\mathrm{JK}^{b} の 1$ 例, 日赤医学, $27: 160,1974$.

12）伊原 治, 三芳 端, 古屋清一他：抗 $\mathrm{JK}^{\circ}$ 抗体之抗 E抗体保有患者におこった輸血副作用について， 日本渝血学会雅誌，26：193-194， 1977.

13）伊東満子，杉山明子，辻村敦子他：輸血によって生 したと思われる不規則抗体 $\mathrm{JK}^{b}+$ 抗 $\mathrm{E}+\mathrm{C}$ の 1 例, 䠛床病理, $27: 713 ， 1979$.

14）只野寿太郎, 南需文夫, 小島久美子：臨床検查室に おりる不規則抗体の検出と分析，臨床病理，27： 60-64, 1979.

15）富田忠夫, 大久保康人, 永尾暢夫他：過去 3 力年の 供血者，受血者の不規則抗体について，徫生涘査， $28: 473,1979$.

16）伊藤圭一, 古川正婎, 岡田博康他：抗 $\mathrm{JK}^{a}$ 抗体の 1 例について，日本榆血学䆶誌，25：135，1979。

17）田中球子, 棚橋定衛, 椎谷幸子他：抗 $E_{1}$, 抗 Fyb, 抗 $\mathrm{JK}^{\circ}$ ，抗体を有した 1 症例並びに過去 5 年間に おける抗体検出状況，日本病院会誌，26：63，1979.

18) Howard, P.L.: Delayed hemolytic transfusion reactions. Ann. Clds. Lab. Sci. 3: 13, 1973.

19）遠山博：䑳血の副作用と対策，内科，48： $612-616,1981$

20) Kronenberg, H., Kooptzoff,O. and Walsh, R.J. : Haemolytic transfusion reaction due to antiKidd, Aust. Ann. Med., $7:$ 34, 1958.

21) Matson G.A., Swanson,J. and Tobin, J.D.: Severe hemolytic disease of the newborn caused by anti-JK ${ }^{a}$. Vox sang, 4:144, 1959.

22) Dorner, I.: Combined maternal erythrocyte autosensitization and materno-fetal $\mathrm{JK}^{a}$ imcompatibility, Transfusion, 14:212, 1974. 